\section{Self mutilation as a feature of Addison's disease}

Psychiatric symptoms reported in Addison's disease tend to be non-specific: lethargy and lassitude are the most common. Addison himself described a patient who developed depression eight years and again six months before his death from the disease. ${ }^{1}$ We report a case of longstanding self mutilitation that regressed completely after treatment for previously unsuspected adrenocortical insufficiency.

\section{Case report}

A girl aged 14 years 10 months presented in June 1981 with a three year history of self mutilation. She repeatedly gouged pieces of skin from her arms and legs every night before falling asleep. The wounds healed with dense pigmentation. She came from an intact family and was the second of three children, all born when the parents were in their teens. She was socially inept, a poor communicator with little ability to make relationships with her peers, and often silent and withdrawn, and her playtime companions were younger boys. Her condition changed little despite fairly intensive counselling of the family.

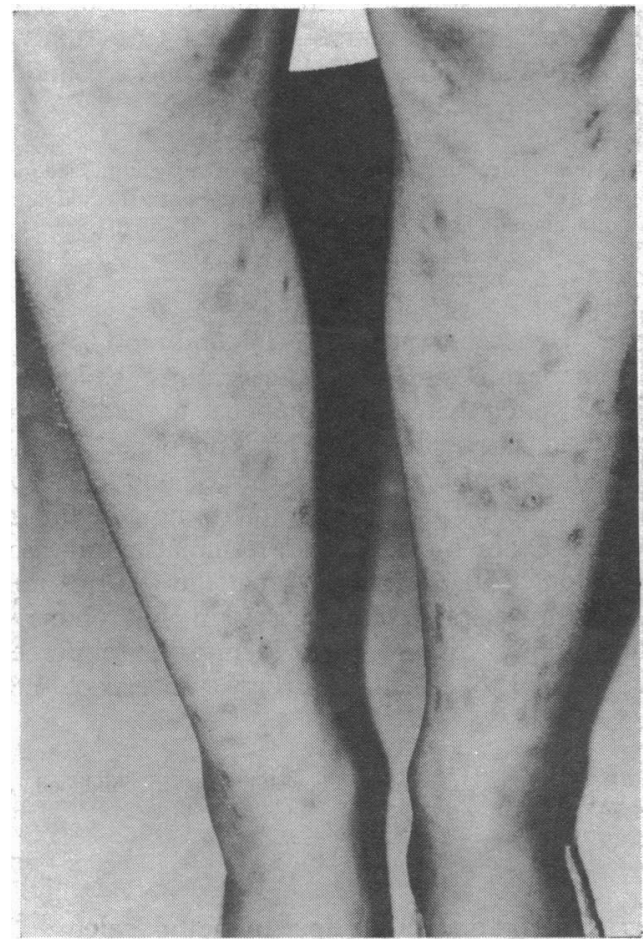

Multiple scars on both legs caused by self mutilation.

In September 1982 while on holiday in Spain she developed nausea, vomiting, dizziness, and tiredness necessitating admission to hospital. Her prasma cortisol concentration was $192 \mathrm{nmol} / 1(7 \mu \mathrm{g} / 100 \mathrm{ml})$, serum sodium concentration $126 \mathrm{mmol}(\mathrm{mEq}) / 1$, and serum potassium concentration $6.2 \mathrm{mmol}(\mathrm{mEq}) / 1$. Addison's disease was diagnosed, and she was treated with steroids. On her return to the United Kingdom she presented to our unit. Her symptoms of Addison's disease had already improved, and examination showed numerous healing pigmented wounds over her arms and legs but no evidence of any recent lesions.

Further investigations at this hospital showed plasma cortisol concentration at 9 am $260 \mathrm{nmol} / 1(9.45 \mu \mathrm{g} / 100 \mathrm{ml})$ and plasma adrenocorticotrophic hormone concentration raised at $184 \mathrm{pmol} / \mathrm{l}(836 \mathrm{ng} / \mathrm{l})$. A short Synacthen test yielded a flat response (plasma cortisol concentration at 30 minutes was only $170 \mathrm{nmol} / 1(6 \cdot 18 \mu \mathrm{g} / 100 \mathrm{ml})$. Serum thyroxine concentration was $26.7 \mathrm{pmol} / 1(2.05 \mathrm{ng} / 100 \mathrm{ml})$, but results of a thyrotrophin releasing hormone test were normal. Adrenocortical antibodies were present and thyroid and parietal cell antibodies absent; results of $x$ ray examination of chest, pituitary fossa, and adrenals were normal. Haemoglobin concentration was $12.5 \mathrm{~g} / \mathrm{dl}$, white cell count $8.5 \times 10^{8} / 1$ (eosinophils $8 \%$ ), and erythrocyte sedimentation rate $8 \mathrm{~mm}$ in first hour. Plasma electrolyte, blood urea, blood glucose, and plasma calcium concentrations were normal. Serum uric acid concentration was also normal at $0.32 \mathrm{mmol} / 1(5.44 \mathrm{ng} / 100 \mathrm{ml})$.
Her condition was subsequently well controlled, with normal adrenocorticotrophic hormone concentrations, with hydrocortisone $20 \mathrm{mg}$ in the morning and $10 \mathrm{mg}$ in the evening. Fludrocortisone was temporarily stopped after three months because of fluid retention.

Her mother reported that self mutilation stopped within one week after steroid treatment began. It did not return over the ensuing six months. Psychiatric interview showed that her demeanour had changed considerably: she was relaxed and communicative. She was working and planned to study further. She no longer chose younger male companions with whom to socialise, and her former suspicion and hostility to others with accompanying gaze avoidance and isolation, had quite disappeared. She was becoming more confident and independent.

\section{Comment}

Behavioural disorders in children tend to be associated with disharmony between the parents, ${ }^{2}$ but this patient had a warm, close, and supportive family. The dramatic self mutilitation of the LeschNyhan syndrome occurs only in boys. ${ }^{3}$ This girl probably had Addison's disease for as long as she was mutilating her limbs. A possible link may be an excess of endorphins in associa.ion with overproduction of adrenocorticotrophic hormone. Endorphins can induce immobility and a "blunted" affect-a condition of near anaesthesia. ${ }^{4}$ Whatever the mechanism, the dramatic and sustained improvement with steroid replacement suggests that adrenocortical insufficiency was the main cause of her serious emotional difficulties.

${ }^{1}$ Addison T. On the constitutional and local effects of disease of the suprarenal capsules. London: D Highley, 1855.

2 Whitehead L. Sex differences in children's responses to family stress: a re-evaluation. $f$ Child Psychol Psychiatry 1979;20:247-54.

${ }^{3}$ Lesch M, Nyhan WL. A familial disorder of uric acid metabolism and central nervous system function. Am $\mathcal{F}$ Med 1964;36:561-70.

4 Clement-Jones V, Besser GM. Clinical perspectives in opioid peptides. Br Med Bull 1983;39:95-100.

(Accepted 21 fune 1983)

Endocrine Unit and Department of Child Psychiatry, District

General Hospital, Sunderland, Tyne and Wear SR4 7TP

A RAJATHURAI, MB, MRCP, senior registrar in medicine

B I CHAZAN, MD, FRCP, consultant physician

J E JEANS, MB, MRCPSYCH, consultant child psychiatrist

Correspondence to: Dr B I Chazan.

COMPOUNDS, SPIRIT AND COMPOUND DISTILLED WATERS-Before begin these, I thought good to premise a few words: They are all hot in operation, and therefore not to be meddled with by people of hot constitutions when they are in health, for fear of fevers and adustion of blood, but for people of cold constitutions, as melancholy and flegmatic people. If they drink of them moderately now and then for recreation, due consideration being had to the part of the body which is weakest, they may do them good: yet in diseases of melancholy, neither strong water nor sack is to be drank, for they make the humour thin, and then up to the head it flies, where it fills the brain with foolish and fearful imaginations.

Let all young people forbear them whilst they are in health, for their blood is usually hot enough without them.

Have regard to the season of the year, so shall you find them more beneficial in Summer than in Winter, because in summer the body is always coldest within, and digestion weakest, and that is the reason why men and women eat less in Summer than in Winter.

Thus much for people in health, which drink strong waters for recreation. (Nicholas Culpeper (1616-54) The Complete Herbal, 1850.)

ECHIUM Viper's-bugloss, Viper's-herb, Snake bugloss, Wal-bugloss, Wild-bugloss, several counties give it these several names: It is a singular remedy being eaten, for the biting of venomous beasts: continually eating of it makes the body invincible against the poison of serpents, toads, spiders, \&c. however it be administered; it comforts the heart, expels sadness and melancholy. The rich may make the flowers into a conserve. and the herb into a syrup, the poor may keep it dry, both may keep it as a jewel. (Nicholas Culpeper (1616-54) The Complete Herbal, 1850.) 